\title{
The Role of Formal Theory in Social Work Research: Formalizing Family Systems Theory
}

\author{
Suzanne Taylor Sutphin \\ Shannon McDonough \\ Amber Schrenkel
}

\begin{abstract}
Formal theories are critical to accumulating knowledge through scientific research to advance the discipline and practice. The use of formal theory in social work research is currently absent. Family Systems Theory (FST) is commonly used in social work; however, it currently lacks the criteria to be considered a formal theory. We use FST to demonstrate the formalization process and its potential effect on social work research and practice. Currently, FST is being used as a perspective, to develop theories and models used in marriage and family therapy, and to develop assessment tools. We identify the components of a formal theory while presenting a formal version of FST. Directions for future research are suggested including the benefits of using formal theory to direct scientific research and guide the development of evidence-based practice.
\end{abstract}

Keywords: Family systems theory, formal theory, social work research

"The fact that human beings create theories testifies to their genius and uniqueness as the only known organisms who are able to conceptualize their own experience" (Becvar \& Becvar, 1982, p. 55).

Social science theories, especially theories of the family, are frequently used by social work researchers and practitioners. However, like many theories applied in social work, the critical components that make the theory scientifically testable are not forthcoming. Therefore, much of the practice in social work related to family theories does not have a solid scientific base. Formalizing theory involves developing the critical components to increase its scientific testability with a focus on adding to cumulative knowledge in the field. This is accomplished by ensuring the deductive logical consistency of the theory, the clear definition of terms, and the explicit designation of the scope conditions under which the theory applies. We focus on a commonly used perspective in social work research, Family Systems Theory (FST), as an example of formalizing a theory. This article briefly reviews the current state of theory in social work, defines FST and how it is currently used in social work practice, and presents the essential components of formal theories along with a formalized version of FST. Finally, we suggest directions for future research relevant to formalized theories.

\section{Theories in Social Work}

The role of theory in social work research has long been critiqued. Kirk and Reid (2002) argue that the current social work knowledge base is "not the product of rigorous scientific testing” (p. 20). The authors also propose that "the 'soft' nature of social work

\footnotetext{
Suzanne Taylor Sutphin, Ph.D., is a Research Assistant Professor at The Center for Child and Family Studies in the College of Social Work at the University of South Carolina in Columbia, SC; Shannon McDonough, MA, is an Instructor of Social Sciences at Allen University in Columbia, SC; and Amber Schrenkel is a 2013 MSW graduate of the College of Social Work at the University of South Carolina in Columbia, SC.
} 
knowledge impedes cumulative knowledge-building efforts” (Kirk \& Reid, 2002, p. 25). Sibeon (1991) echoes that sentiment and points out that "different types of social work cognitions are drawn upon by practitioners in different historical periods, but their common denominator is that, with very few exceptions, none of them are drawn from academic disciplinary discourses” (p. 143).

The professional concern is that while social work scholars identify many theories in their research and practice, most are not formal theories, and many are merely perspectives. This was evident in the work of Gentle-Genitty and colleagues (2007). The authors rated articles in social work journals based on their inclusion of theory. Of their sample of over 1,000 articles, only $6 \%$ met their more rigorous standard of including theory with an empirical base. In fact, the authors found that most of the journals had only a small focus on theory altogether. Gentle-Genitty and colleagues (2007) proposed that "theory discussion may be defined as a superficial description of the theory that does not include exploration of the components or empirical base of the theory" (p. 65).

Longstanding formal theories must have empirical support (Kirk \& Reid, 2002). The development, testing, and application of formal theories allows researchers to systematically revise and expand theories and leads to cumulative knowledge, which, ultimately, advances understanding of the phenomenon in question (Cohen, 1989; Freese, 1980; Payne, 1997; White, 2005). Turner (1998) proposes that theories used to solve problems evident in real-world settings will ultimately strengthen the theory. Therefore, formal theories can enhance both theoretical research as well as empirical research used in real world applications.

As an example in the following sections, we will focus on one theory commonly used in social work research and practice, Family Systems Theory (FST). We present an overview of FST to provide a basis of formalizing the theory; it is not intended to be a comprehensive review of the theory.

\section{Family Systems Theory}

Family Systems Theory describes the processes that affect the ideal functioning of a family thereby causing disorder (Dore, 2008). The main purpose of FST is to inform the "understanding and interpretation of the cognitive, social, and emotional functioning of individuals in society" (Dore, 2008, p. 435). In therapeutic settings, FST emphasizes treating the whole family when treating a deviant family member(s). ${ }^{i}$ The causes of a family's problems are viewed as circular and the therapist attempts to modify family communication patterns to alter the interactions so that the family returns to a healthier state of functioning (Howe, 1991).

Families are seen as systems that may become dysfunctional and that can return to a healthier state of functioning, referred to as homeostasis, by altering communication patterns and interactions, internal and external boundaries, and/or redefining or restructuring family roles and subsystems. Payne (1997) describes that some scholars propose that individuals are dependent on systems such that informal systems (e.g., families), are nested in formal systems, (e.g., communities, neighborhoods), which are nested in societal systems, (e.g., schools, government). In other words, families are not 
only affected by their internal boundaries and interactions, but are also influenced by the larger systems in which they reside.

\section{Family Systems Theory in Social Work Practice}

One of the motivators to use FST as the example in this process was because of its utilization and applicability in social work research and practice. A review of literature on FST in social work reveals that FST is applied in three main ways: (1) as a perspective to approach a certain topic or research question, (2) as a model to treat families in therapeutic settings, and (3) for the development of assessment tools.

\section{Family Systems Theory as a Perspective}

In exploring how FST is applied in social work research, a majority of articles reviewed use the theory as a perspective by adopting the view that individuals in crisis should be evaluated within the family system and that interventions should involve the whole family in order to have any effect on the individual in question (Bartle-Haring, 1997; Bilgin, Cenkseven, \& Satar, 2007; Bradbury \& Marsh, 1988; Bray \& Harvey, 1991, 1992; Brooks, 1999; Brooks \& Ronen, 2006; Delsing, Oud, De Bruyn, \& van Aken, 2003; Franck \& Buehler, 2007; Hammer, Neal, Newsom, Brockwood, \& Colton, 2005; Hughes \& Gullone, 2008; Johnson, 2003; Katz, 1977; Richmond \& Stocker, 2006, 2008; Skowron, 2000). FST as a perspective is also used to support the application of family preservation services (Cimmarusti, 1992; Walton \& Smith, 1999) and family group conferencing (Brooks \& Ronen, 2006).

These articles still fail to test a formal theory. Rather, they briefly discuss FST by laying out a few concepts and assumptions from which they form hypotheses or research questions. Without testing hypotheses that are logically derived from a formalized theory, FST cannot be properly tested and revised to produce cumulative knowledge. While informal theories and perspectives can play a crucial role in the early development of a formal theory, using theories without the intent of building a formal theory does not accumulate knowledge due to the lack of technical and formal language and the inconsistent definition of terms, which leave perspectives too open to interpretation (Klein \& Jurich, 1993).

\section{Family Systems Theory as Part of Models Used in Therapeutic Settings}

Another factor in the need to formalize FST is its use in developing techniques and models used in marriage and family therapy. Becvar and Becvar (1982) describe in detail how systems theory can be used in family therapy. The authors propose that the theory allows for the family to be treated as a network of systems including the individuals, the family system, and the social system in which they live (Becvar \& Becvar, 1982). Several therapeutic techniques and models have been developed that use tenets of systems theory and FST when helping families in stressful or crisis situations.

Therapeutic techniques using aspects of systems theory. Many well-regarded therapeutic techniques have been developed using aspects of systems theory. Based on the works of Haley and Madanes, strategic family therapy uses aspects of systems theory 
by shifting the focus in therapy from the individual to the family and the role of the therapist in developing strategies to address the problem. The goals of the techniques used in the therapy focus on changing the family structure to modify behavior (Madanes, 1981). Importantly, Haley's therapy strategies call for therapists to examine the individual needing treatment within the context of the family and the larger society (Haley, 1972, 1978).

Developed by Minuchin, structural family therapy also views the individual in the context of his family unit and social environment (Minuchin, 1974). In this form of therapy, the family and the therapist are treated as a system to monitor behavior. The family system receives the intervention to modify behavior and promote family functioning.

As proposed by Gottman, the sound marital house focuses on marital therapy as a means to predict various outcomes and satisfaction in relationships and to identify qualities that make for a lasting relationship such as establishing a friendship in the marital couple. The theory focuses on a systematic approach in that the behavior of one partner affects the other (Gottman, 1999; Gottman, Driver, \& Tabares, 2002).

Emotionally focused couple therapy (EFT) is a synthesis of approaches that are designed to help couples in crisis navigate their emotions and emotional responses. The therapy draws on perspectives and premises of experimental therapies, family systems theory, and attachment theory. The authors point out that different family therapists use different techniques of breaking negative family cycles when incorporating FST into their therapies (Johnson \& Denton, 2002).

Models using aspects of FST. Several models have been developed using FST. The Double ABCX Family Crisis Model incorporates aspects of systems theory by examining how stressors, such as becoming a parent, impact the family as a whole (McCubbin \& Patterson, 1983). The Circumplex Model of Marital and Family Systems, based largely on systems theory, is designed to treat family systems by integrating cohesion, flexibility, and communication to promote family functioning (Olson \& Gorall, 2003).

The Beavers Systems Model is based on five central concepts related to family functioning, family competence, behavioral style, family assessment, and task competence to assess functionality. The Beavers Systems Model also incorporates elements of systems theory by examining the family system when determining how a therapist should engage the family (Beavers \& Hampton, 2003). Franck and Buehler (2007) developed a model from FST, which lays out general knowledge claims and hypotheses to test concepts pertaining to marital hostility and parental depressive affect as stressors for youth.

\section{Using Family Systems Theory to Inform Assessment Tools}

FST has been used to support an argument for the use of social work assessment tools (Asarnow, Berk, \& Baraff, 2009; Bilgin et al., 2007; Bray \& Harvey, 1992; Brooks, 1999; Brooks \& Ronen, 2006; Cimmarusti, 1992; Martin, Miller-Johnson, Kitzman, \& Emery, 1998; Walton \& Smith, 1999). Many studies reveal a number of assessment tools 
that may be used to identify and measure instantiations of important concepts in FST such as the Parent-Adolescent Relationship Questionnaire/Inventory (PARQ) (Bilgin et al., 2007), the Family System Test (FAST) (Gehring, Debry, \& Smith, 2001), the Family Adaptability and Cohesion Scales (FACES) (Olson \& Gorall, 2003) and the Self-Report Inventory (Beavers \& Hampton, 2003).

Since FST has many important real world applications, it is therefore beneficial to formalize FST. Thus, a formalized version of FST could easily be tested using these available measurement tools, which would strengthen its explanatory and predictive power as a scientific theory. This would also be helpful in the development of evidencebased practices as discussed in future research.

The following theory constitutes what we identify as the core of FST. We describe the critical components of formal theory and demonstrate the formalization process of FST. We then discuss the applicability of the theory for social work research and practice.

\section{Formalizing Family Systems Theory}

"Theory" as a concept has previously been used in many different ways and defined to include other concepts such as ideas or hypotheses. This can make any generalization impossible, and promotes "mindless eclecticism" and a "lack of rigorous analysis" due to an "anything goes" approach to theory (Doherty, Boss, LaRossa, Schumm, \& Steinmetz, 1993, pp. 18-19), which is found to be common in social work research and practice. According to Papero (2006) "The term theory contains within it the assumption that such propositions represent the best current thinking about the phenomenon, an established framework within which known facts can be explained. From such theoretical thinking comes all therapeutic methodology" (p. 45). Thus, social work research could extensively benefit from formalizing theories.

Since the accumulation of knowledge and findings is a key function of theories (White, 2005), we argue that using formal theories, from which hypotheses can be logically derived, is the ideal approach to conducting research. In fact, the process of building and revising formal theories is a primary way to advance theory and knowledge, while also lending widespread credibility to the field in question (White, 2005).

\section{Components of Formal Theory}

The scientific method distinguishes theories from perspectives. Whereas perspectives offer a way of thinking about the world, theories provide a way to test logically derived hypotheses about why things happen (Payne, 1997). Based on the scientific method, “'theory' must explain in a provable way why something happens, not simply describe it in an organized way or provide a way of thinking about the world" (Payne 1997, p. 35). Cohen (1989) defines a scientific theory as "a set of interrelated statements, some of which are definitions and some of which are relationships assumed to be true, together with a set of rules for the manipulation of these statements to arrive at new statements" (p. 71). Thus, formal theory requires a number of properties that distinguishes it from

informal theories, quasi-theories, or perspectives. Specifically, formal theories must 
consist of: meta-theory, primitive and explicitly defined terms, scope conditions, logically structured propositions that are interrelated and testable, and derived propositions (Cohen, 1989; Freese, 1980).

All of these components of a formal theory allow for theory to be intersubjectively testable (Cohen 1989; Freese 1980). That is, formal theory reduces the latitude for multiple subjective interpretations of the theory, which fosters empirical evaluations of the theory that are more consistently valid among different researchers. This also allows for research programs to operate efficiently and productively (Cohen, 1989; Wagner \& Berger, 1985). Therefore, when a formal theory is properly tested, knowledge gained from testing the theory becomes cumulative. Ultimately, "If you know theory you can use it. If you don't you can't” (as cited in Gilbert, 2006, p. 3).

\section{Meta-Theory}

Meta-theory is essentially a theory about a theory. Specifically, meta-theory is often used as a "source of perspectives that overarch sociological theory" (Ritzer, 1990, p. 4). In other words, meta-theory is developed through a systematic study of a theory. The role of this type of meta-theory is to provide an overarching perspective that explains the foundational concepts, ideas, and statements behind a theory, including general statements about how society operates. The following meta-theory developed for the formalized version of FST includes general systems theory as a foundational view of society within which family systems exist. Also, the following meta-theory presents some of the foundational concepts and ideas of FST to provide a general foundation upon which the formalized theory is based.

Family Systems Theory. Family systems theory was developed in the 1960s from general systems theory (Dore, 2008). As it relates to the social sciences, general systems theory provides a link between the macro and micro levels of analysis and shows the interconnected relationship between the two levels. An important feature of general systems theory is to regard the system as a whole and not solely focus on the individual parts to understand how the system works. FST describes the processes by which families that have moved out of homeostasis (the ideal state of family functioning) return to homeostasis. Homeostasis can be thought of as a balance between a family's level of enmeshment (dependence) and disengagement (interdependence).

Applying systems theories to families views individual family members in the context of the whole family and focuses on relationships between family members (Becvar \& Becvar, 1982; Howe, 1991). The theory focuses on the effects of a cycle of interactions and behaviors that cause problems within families (Becvar \& Becvar, 1982). Information is the energy that maintains the system. Family systems with a higher rate of energy flow are less likely to be stabilized. Systems that do not properly process energy flow are pushed toward a state of maximum disorder or entropy. That is, they are pushed out of homeostasis.

What Causes a Family to Move Out of Homeostasis? As described below, since FST explains the process by which families move back into homeostasis, it is important to review the types of stressors that can initially cause a family to move out of homeostasis. 
The book, Stress and the Family, reviews a number of stressors, both normative and catastrophic, that can cause a family crisis (Figley \& McCubbin, 1983; McCubbin \& Figley, 1983). Specific instances of family distress discussed, which can also be identified as having the potential to move a family out of homeostasis, consist of both normative stressors that families commonly face and catastrophic stressors, which are much less common and often more debilitating (Figley \& McCubbin, 1983; McCubbin \& Figley, 1983). Normative stressors include ambiguous boundaries in the marital relationship, sexual development over the life course, various stresses of parenthood (e.g., financial, physical, and psychological stressors), adolescent development, stressors of dual-career families (e.g., role strain, impact on children, balancing work and family), divorce, single parenting, step parenting or blending families, environmental stress, societal stress, and economic stress (McCubbin \& Figley, 1983). Catastrophic stressors discussed include chronic illness, drug abuse, physical abuse, abandonment, death, unemployment, rape/sexual abuse, natural disasters, war, and captivity (Figley \& McCubbin, 1983).

\section{Terms and Definitions}

Without clearly defined terms, a theory cannot be validly tested. The precise definition of terms provides a consensus among researchers regarding what exactly constitutes a concept, which has implications for how it will be operationalized in any derived hypotheses. When formalizing a theory, all terms which are included in other definitions, in the scope conditions, and in the propositions must be defined. The definitions are not written to be empirically testable themselves, but are written to be operationalized in a number of ways in a variety of empirical settings.

All terms in a theory cannot be defined. The terms used in the theory are either primitive or defined. Primitive terms have a widely agreed upon meaning and require no written definition while defined terms consist of both primitive terms and other previously defined terms used for specification of meaning. Terms should also be presented in terminological order. Presenting terms in terminological order allows the definitions to build upon each other, meaning new terms consist only of primitive terms and previously defined terms.

Table 1 presents the defined terms of FST, as identified in the literature, used to develop the formal theory. We have included a column that provides the citation for other models that examine families as a system that use the same terms. For models that use similar terms for the same concept, the term is also provided.

\section{Scope Conditions}

Scope conditions define under what circumstances a theory applies. Thus, a test of a theory must fall under specified scope conditions for the test to be valid. This helps to reduce a common problem found in social science research, where a theory is falsified under one empirical examination while being supported by another. The goal is to relax the scope conditions as the theory continues to be tested and applied in various conditions to increase confidence in the applicability of the theory. 
Table 1. Defined Terms in Terminological Order*

\begin{tabular}{|c|c|c|}
\hline Term & Definition & Terms From Other Models \\
\hline System & $\begin{array}{l}\text { a group of interacting and } \\
\text { interdependent actors that function } \\
\text { individually to form a complex whole }\end{array}$ & $\begin{array}{l}\text { Beavers \& Hampton (2003); } \\
\text { Franck \& Buehler (2007); } \\
\text { Johnson \& Denton (2002); Haley } \\
\text { (1978); Madanes (1981); } \\
\text { McCubbin \& Patterson (1983); } \\
\text { Minuchin (1974); Olson \& } \\
\text { Gorall (2003) }\end{array}$ \\
\hline Boundaries & $\begin{array}{l}\text { delineates what is inside or outside of } \\
\text { a system }\end{array}$ & $\begin{array}{l}\text { Beavers \& Hampton (2003); } \\
\text { Franck \& Buehler (2007); } \\
\text { McCubbin \& Patterson (1983); } \\
\text { Minuchin (1974) }\end{array}$ \\
\hline Family & $\begin{array}{l}\text { a system that has: (1) two or more } \\
\text { interacting individuals, (2) related by } \\
\text { marriage, birth, or adoption or } \\
\text { voluntarily committed to each other } \\
\text { as a unit to promote well-being, (3) } \\
\text { identify themselves as a family }\end{array}$ & $\begin{array}{l}\text { Beavers \& Hampton (2003); } \\
\text { Franck \& Buehler (2007); Haley } \\
\text { (1978); Madanes (1981); } \\
\text { McCubbin \& Patterson (1983); } \\
\text { Minuchin (1974); Olson \& } \\
\text { Gorall (2003) }\end{array}$ \\
\hline Pattern & $\begin{array}{l}\text { the recognition of a repeated event by } \\
\text { an observer }\end{array}$ & $\begin{array}{l}\text { Beavers \& Hampton (2003); } \\
\text { Johnson \& Denton (2002); } \\
\text { McCubbin \& Patterson (1983); } \\
\text { Minuchin (1974) }\end{array}$ \\
\hline Norm & $\begin{array}{l}\text { implicit or explicit guidelines for } \\
\text { behavior }\end{array}$ & Olson \& Gorall (2003) \\
\hline Relationship & a norm-based pattern of interaction & $\begin{array}{l}\text { Beavers \& Hampton (2003); } \\
\text { Olson \& Gorall (2003) }\end{array}$ \\
\hline Subsystem & $\begin{array}{l}\text { system in a larger system that has its } \\
\text { own boundaries and norms }\end{array}$ & Minuchin (1974) \\
\hline Internal Boundary & $\begin{array}{l}\text { delineates subsystems within a } \\
\text { system }\end{array}$ & Minuchin (1974) \\
\hline $\begin{array}{l}\text { External } \\
\text { Boundary }\end{array}$ & $\begin{array}{l}\text { delineates a system from the larger } \\
\text { social system }\end{array}$ & Beavers \& Hampton (2003) \\
\hline $\begin{array}{l}\text { Emotional } \\
\text { Boundary }\end{array}$ & $\begin{array}{l}\text { delineates what are appropriate levels } \\
\text { of attachment and characteristics of } \\
\text { behavior between two or more family } \\
\text { members }\end{array}$ & $\begin{array}{l}\text { Family cohesion - Olson \& } \\
\text { Gorall (2003) }\end{array}$ \\
\hline Enmeshment & $\begin{array}{l}\text { absence of emotional boundaries } \\
\text { between family members }\end{array}$ & $\begin{array}{l}\text { Beavers \& Hampton (2003); } \\
\text { Minuchin (1974); Olson \& } \\
\text { Gorall (2003) }\end{array}$ \\
\hline
\end{tabular}


Table 1. (cont.)

\begin{tabular}{lll}
\hline Disengagement & $\begin{array}{l}\text { rigid emotional boundaries between } \\
\text { family members }\end{array}$ & $\begin{array}{l}\text { Franck \& Buehler (2007); Haley } \\
\text { (1978); McCubbin \& Patterson } \\
\text { (1983); Minuchin (1974); }\end{array}$ \\
& & Gottman (1999); Olson \& Gorall \\
(2003)
\end{tabular}




\begin{tabular}{|c|c|c|}
\hline Goal & desired state that motivates behavior & $\begin{array}{l}\text { Gottman (1999); Haley (1978); } \\
\text { Madanes (1981); McCubbin \& } \\
\text { Patterson (1983); Minuchin } \\
\text { (1974); Olson \& Gorall (2003) }\end{array}$ \\
\hline Self-reflexive & $\begin{array}{l}\text { the ability to observe and evaluate } \\
\text { oneself }\end{array}$ & - \\
\hline Entropy & maximum disorder in a system & $\begin{array}{l}\text { Unbalanced - Olson \& Gorall } \\
\text { (2003) }\end{array}$ \\
\hline $\begin{array}{l}\text { First-order } \\
\text { Change }\end{array}$ & $\begin{array}{l}\text { an individual family member has } \\
\text { changed }\end{array}$ & $\begin{array}{l}\text { First level balance - McCubbin } \\
\text { \& Patterson (1983) }\end{array}$ \\
\hline $\begin{array}{l}\text { Second-order } \\
\text { Change }\end{array}$ & the family structure has changed & Olson \& Gorall (2003) \\
\hline Self-regulating & $\begin{array}{l}\text { the internal ability to sustain the } \\
\text { family system }\end{array}$ & $\begin{array}{l}\text { Minuchin (1974); Gottman } \\
\text { (1999) }\end{array}$ \\
\hline
\end{tabular}

* Note: Any undefined terms are considered primitive terms.

The scope of the theory carries important implications. For example, in a critique of FST, Pam (1993) uses an example of a family therapist who used a systems approach to resolve a disagreement between an administrator and an employee. The author argued that the systems viewpoint of the therapist in examining the system effects instead of the individuals was "convoluted” (Pam, 1993, p. 86). In formalizing FST, we limit the theory to family systems, which we defined as part of our scope conditions. Restricting the scope of the theory to family systems, as defined in the previous section, would prevent this example from being used as a critique of FST because a relationship between colleagues falls outside the scope of the theory. Therefore, we have identified the following scope conditions.

This theory applies to families that:

1. are hierarchical

2. have boundaries

3. interact in patterns

4. have individuals who are interdependent

5. have rules

6. have subsystems

This theory applies to family systems that:

1. are self-reflexive

2. are goal-seeking

3. are self-regulating 


\section{Propositions}

Propositions are logically interrelated knowledge claims that make up the core of the theory. Requiring the propositions to be logically interrelated reveals any contradictory claims and allows for logical generations of new relationships or derivations. These claims can be true or false. That is, theories that are truly scientific have propositions that are able to be falsified (Kirk \& Reid, 2002). Based on our review of the literature, as described in the previous sections, we developed the following core set of propositions where $\mathrm{D}=$ the level of disengagement and $\mathrm{E}=$ the level of enmeshment:

1. If $\mathrm{D}>\mathrm{E}$, then $\mathrm{D}$ must be decreased OR $\mathrm{E}$ must be increased (to make $\mathrm{D}=\mathrm{E}$ ) to move toward homeostasis.

1a. If disengagement increases or enmeshment decreases, then the family's internal boundaries become more rigid.

1b. If internal boundaries become more rigid, then the communication within and across subsystems in the family system becomes more inhibited and infrequent.

2. If $\mathrm{D}<\mathrm{E}$, then $\mathrm{E}$ must be decreased OR $\mathrm{D}$ must be increased (to make $\mathrm{D}=\mathrm{E}$ ) to move toward homeostasis.

2a. If disengagement increases or enmeshment decreases, then the family's external boundaries become more permeable.

2b. If external boundaries become more permeable, then the family becomes more open to influence from the suprasystem.

2c. If the family is open to influence from the suprasystem that is unsupportive, then they are less likely to be in homeostasis.

3. If a family is not in homeostasis, then the family is moving towards a state of entropy.

4. If a family is moving towards a state of entropy, then they enter a (negative or positive) feedback loop.

4a. If the family enters a negative feedback loop, then they return to a morphostatic state of homeostasis.

4b. If the family enters a positive feedback loop, then the system moves to a morphogenetic state of homeostasis as the result of either a first order change or second order change.

\section{Discussion}

Dore (2008) proposes FST is the family theory that has the most relevance and salience for social work practice. Formalizing FST allows for more scientific research to be conducted in this area to further advance the discipline. Using a formal theory will allow for better implementation of the current uses of theory in social work models and assessment tools. The theory formalization process, as demonstrated in this article, significantly contributes to the literature by providing a solid basis to test the theory and 
expand and develop certain aspects of the theory such as adding propositions and further defining the scope conditions under which the theory applies as discussed below.

Herz and Johansson (2012) point to the shift in using the scientific method when exploring social problems. We propose that this is done successfully by formalizing theories. Through our formalization of FST, we hope to impress the need for the development and use of more formal theories in social work research. Formalizing theories allows for more accurate tests of the theory and leads to the accumulation of knowledge. An increase in the number of formal theories will continue to lend credibility to social work as a social science discipline capable of conducting cumulative scientific research.

Connecting theory to methods and practice advances cumulative knowledge (Turner, 1998). Future research should continue to formalize commonly used theories and work on establishing a cumulative body of knowledge through the development of research programs in social work. Family theories could be an example of such research programs. For example, future research could formalize Bowen Theory, which would therefore provide a more useful connection between Bowen Theory and FST. Research based on the collaboration of these two theories could be used in therapeutic settings. We have presented a core set of propositions based on current literature. Researchers can then begin to add more propositions, through rigorous testing, to develop a more comprehensive theory and contribute to the scientific knowledge in the profession.

In addition to adding propositions, the scope of the theory could potentially be expanded to take into account cultural variations of family interactions. For example, the formalized version of FST presented would be less applicable within cultures that value enmeshment or high levels of cohesion in families. Dore (2008) pointed out that "[I]t is important to highlight that any assessment of enmeshment and disengagement in families must take into account the cultural context of the family system. Some cultures value a high level of emotional involvement among family members; other cultures reward emotional distance and self-containment” (p. 449). Additionally, Walsh (2003) described that normal family processes are socially constructed and therefore function in terms of the cultural context in which the family resides. Specifically, a functional family in one cultural setting may be dysfunctional in another setting depending on the specific cultural values and norms within the setting. Therefore, future tests of formal theory may reveal that it is necessary to add scope conditions to the theory that define the cultural setting.

The applicability of theory, such as FST, extends beyond social work research and practice to family therapy. Our review of therapies that include aspects of systems theory and specifically FST provides an overview of the usefulness of the theory in therapeutic settings. The therapies reviewed are grounded in theory to develop their techniques for treating individuals in the context of their family system. Continuing to develop and refine formal theories can serve as a means to strengthen these techniques.

Finally, the development and use of formal theories in social work research would strengthen the current movement towards evidence-based practice. This movement envisions social work practice based on "the best available evidence to guide practice decisions” (Witkin \& Harrison, 2001, p. 295). As evidence-based practice programs and 
models are research-based (Proctor, 2007), and have evidence of success, the use of formal theory would help to develop a clearer connection from social work research to program planning to daily practice and develop a stronger and deeper scientific knowledge base for the social work profession.

\section{References}

Asarnow, J. R., Berk, M. S., \& Baraff, L. J. (2009). Family intervention for suicide prevention: A specialized emergency department intervention for suicidal youths. Professional Psychology: Research and Practice, 40(2), 118-125.

Bartle-Haring, S. (1997). The relationships among parent-adolescent differentiation, sex role orientation and identity development in late adolescence and early adulthood. Journal of Adolescence, 20(5), 553-565.

Beavers, W. R., \& Hampton, R. B. (2003). Measuring family competence: The Beavers Systems Model. In F. Walsh (Ed.), Normal family processes: Growing diversity and complexity ( $3^{\text {rd }}$ ed., pp. 549-580). New York, NY: The Guilford Press.

Becvar, R. J., \& Becvar, D. S. (1982). Systems theory and family therapy: A primer. Lanham: University of America Press.

Bilgin, M., Cenkseven, F., \& Satar, S. (2007). An analysis of parent-female adolescent relationships in female adolescent suicides. Crisis: The Journal of Crisis Intervention and Suicide Prevention, 28(4), 190-197.

Bowen, M. (2002). Family therapy in clinical practice. Northvale, NJ: Jason Aronson.

Bradbury, S. A., \& Marsh, M. R. (1988). Linking families in preadoption counseling: A family systems model. Child Welfare, 67(4), 327-335.

Bray, J. H., \& Harvey, D. M. (1991). Evaluation of an intergenerational theory of personal development: Family process determinants of psychological and health distress. Journal of Family Psychology, 4(3), 298-325.

Bray, J. H., \& Harvey, D. M. (1992). Intimacy and individuation in young adults: Development of the young adult version of the personal authority in the family system questionnaire. Journal of Family Psychology, 6(2), 152-163.

Brooks, S. L. (1999). Therapeutic jurisprudence and preventive law in child welfare proceedings: A family systems approach. Psychology, Public Policy, and Law, 5(4), 951-965.

Brooks, S. L., \& Ronen, Y. (2006). The notion of interdependence and its implications for child and family policy. Journal of Feminist Family Therapy, 17(3), 23-46.

Cimmarusti, R. A. (1992). Family preservation practice based on multisystems approach. Child Welfare, 67(4), 241-256.

Cohen, B. (1989). Developing sociological knowledge: Theory and method. Chicago, IL: Nelson-Hall. 
Delsing, M. J. M. H., Oud, J. H. L., De Bruyn E. E. J., \& van Aken, M. A. G. (2003). Current and recollected perceptions of family relationships: The social relations model approach applied to members of three generations. Journal of Family Psychology, 17(4), 445-459.

Doherty, W. J., Boss, P. G., LaRossa, R., Schumm, W. R., \& Steinmetz, S. (1993). Family theories and methods: A contextual approach. In P. G. Boss, W. J. LaRossa, W. R. Schumm, \& S. Steinmetz (Eds.), Sourcebook of family theories and methods: A contextual approach (pp. 3-30). New York, NY: Kluwer Academic/Plenum Publishers.

Dore, M. M. (2008). Family systems theory. In B.A. Thyer, K.M. Sowers, \& C.N. Dulmus (Eds.), Comprehensive handbook of social work and social welfare: Human behavior in the social environment (pp. 431-462). Hoboken, NJ: John Wiley and Sons.

Figley, C. R., \& McCubbin H. I. (Eds.). (1983). Stress and the family: Volume II: Coping with catastrophe. New York, NY: Brunner/Mazel.

Franck, K., \& Buehler, C. (2007). A family process model of marital hostility, parental depressive affect, and early adolescent problem behavior: The roles of triangulation and parental warmth. Journal of Family Psychology, 21(4), 614-625.

Freese, L. (1980). Theoretical methods in sociology: Seven essays. Pittsburgh: University of Pittsburgh Press.

Friedman, E. H. (1991). Bowen theory and therapy. In A. S. Gurman \& D. P. Kniskern (Eds.), Handbook of family therapy Vol. 2 (pp. 134-170). NewYork, NY: Brunner/Mazel, Inc.

Gilbert, R. M. (2006). The eight concepts of Bowen theory. Falls Church, VA: Leading Systems Press.

Gehring, T. M., Debry, M., \& Smith, P. K. (Eds.). (2001). The family system test FAST: Theory and application. Philadelphia, PA: Taylor \& Francis.

Gentle-Genitty, C. S., Gregory, V., Pfahler, C., Thomas, M., Lewis, L., Campbell, K., Ballard, K., Compton, K., \& Daley, J. G. (2007). A critical review of theory in social work journals: A replication study. Advances in Social Work, 8(1), 62-80.

Gottman, J. M. (1999). The marriage clinic: A scientifically-based marital therapy. New York, NY: W.W. Norton \& Company, Inc.

Gottman, J. M ., Driver, J., \& Tabares, A. (2002). Building the sound marital house: An empirically derived couple therapy. In A. Gurman \& N. Jacobson (Eds.), Clinical handbook of couple therapy (pp. 373-399). New York, NY: The Guilford Press.

Haley, J. (1972). The family of a schizophrenic: A model system. In G. D. Erickson \& T. P. Hogan (Eds.), Family therapy: An introduction to theory and technique (pp. 5175). Monterey, CA: Brooks/Cole Publishing Company. 
Haley, J. (1978). Problem solving therapy: New strategies for effective family therapy. New York, NY: Harper \& Row.

Hall, C. M. (1981). The Bowen family theory and its uses. New York, NY: Jason Aronson.

Hammer, L. B., Neal, M. B., Newsom, J. T., Brockwood, K. J., \& Colton, C. L. (2005). A longitudinal study of the effects of dual-earner couples' utilization of family-friendly workplace supports on work and family outcomes. Journal of Applied Psychology, 90(4), 799-810.

Herz, M., \& Johansson, T. (2012). 'Doing' social work: Critical considerations on theory and practice in social work. Advances in Social Work, 13(3), 527-540.

Howe, D. (1991). The family and the therapist: Towards a sociology of social work. In M. Davies (Ed.), The sociology of social work (pp. 147-162). New York, NY: Routledge.

Hughes, E. K., \& Gullone, E. (2008). Internalizing symptoms and disorders in families of adolescents: A review of family systems literature. Clinical Psychology Review, 28(1), 92-117.

Johnson, S. M., \& Denton, W. (2002). Emotionally focused couple therapy: Creating secure connections. In A. Gurman \& N. Jacobson (Eds.), Clinical handbook of couple therapy (pp. 221-250). New York, NY: The Guilford Press.

Johnson, V. K. (2003). Linking changes in whole family functioning and children's externalizing behavior across the elementary school years. Journal of Family Psychology, 17(4), 499-509.

Katz, L. (1977). Older child adoptive placement: A time of family crisis. Child Welfare, 56(3), 165-172.

Kirk, S. A., \& Reid, W. J. (2002). Science and social work. New York, NY: Columbia University Press.

Klein, D. M., \& Jurich, J. A. (1993). Metatheory and family studies. In P. G. Boss, W. J. Doherty, R. LaRossa, W. R. Schumm, \& S. K. Steinmetz (Eds.), Sourcebook of family theories and methods: A contextual approach (pp. 31-67). New York, NY: Kluwer Academic/Plenum Publishers.

Madanes, C. (1981). Strategic family therapy. San Francisco, CA: Jossey-Bass, Inc.

Martin, M. T., Miller-Johnson, S., Kitzmann, K. M., \& Emery, R. E. (1998). Parent-child relationships and insulin-dependent diabetes mellitus: Observational ratings of clinically relevant dimensions. Journal of Family Psychology, 12(1), 102-111.

McCubbin, H. I., \& Figley, C. R. (Eds.). (1983). Stress and the family: Volume I: Coping with normative transitions. New York, NY: Brunner/Mazel. 
McCubbin, H. I., \& Patterson, J. M. (1983). Family transitions: Adaptations to stress. In H. I. McCubbin \& C. R. Figley (Eds.), Stress and the family: Volume I: Coping with normative transitions (pp. 5-25). New York, NY: Brunner/Mazel.

Minuchin, S. (1974). Families \& family therapy. Cambridge, MA: Harvard University Press.

Olson, D. H., \& Gorall, D. M. (2003). Circumplex model of marital and family systems. In F. Walsh (Ed.), Normal family processes ( $3^{\text {rd }}$ ed., pp. 514-547). New York, NY: Guilford.

Pam, A. (1993). Family systems theory: A critical view. New Ideas in Psychology, 11(1), 77-94.

Papero, D. V. (2006). Bowen family systems theory. Boston, MA: Allyn and Bacon.

Payne, M. (1997). Modern social work theory. Chicago, IL: Lyceum Books, Inc.

Proctor, E. K. (2007). Implementing evidence-based practice in social work education: Principles, strategies, and partnerships. Research on Social Work Practice, 17(5), 583-591.

Richmond, M. K., \& Stocker, C. M. (2006). Associations between family cohesion and adolescent siblings' externalizing behavior. Journal of Family Psychology, 20(4), 663-669.

Richmond, M. K., \& Stocker, C. M. (2008). Longitudinal associations between parents' hostility and siblings' externalizing behavior in the context of marital discord. Journal of Family Psychology, 22(2), 231-240.

Ritzer, G. (1990). Metatheorizing in sociology. Sociological Forum, 5, 3-15.

Sibeon, R. (1991). Towards a new sociology of social work. Aldershot, UK: Avebury.

Skowron, E. A. (2000). The role of differentiation of self in marital adjustment. Journal of Counseling Psychology, 47(2), 229-237.

Turner, J. H. (1998). Must sociological theory and sociological practice be so far apart?: A polemical answer. Sociological Perspectives, 41, 243-258.

Wagner, D. G., \& Berger, J. (1985). Do sociological theories grow? American Journal of Sociology, 90(4), 697-729.

Walsh, F. (2003). Changing families in a changing world: Reconstructing family normality. In F. Walsh (Ed.), Normal family processes: Growing diversity and complexity ( ${ }^{\text {rd }}$ ed., pp. 3-26). New York, NY: The Guilford Press.

Walton, E., \& Smith, C. (1999). The genogram: A tool for assessment and intervention in child welfare. Journal of Family Social Work, 3(3), 3-20.

White, J. M. (2005). Advancing family theories. Thousand Oaks, CA: Sage Publications.

Witkin, S. L., \& Harrison, W. D. (2001). Whose evidence and for what purpose? Social Work, 46(4), 293-296. 


\section{Author note:}

Address correspondence to: Suzanne Taylor Sutphin, Ph.D., The Center for Child and Family Studies, College of Social Work, University of South Carolina, 226 Bull Street, Columbia, SC 29208. Email: sutphist@mailbox.sc.edu

\footnotetext{
i In a discussion of FST, it is important to point out Bowen Family Systems Theory, or Bowen Theory, which was developed by a psychiatrist, Dr. Murray Bowen (Bowen, 2002; Papero, 2006). Dr. Bowen pioneered the application of family systems theory in a clinical setting (Dore, 2008). Initially constructed using six concepts, the theory is now expanded to include eight interlocking concepts: the nuclear family emotional system, the differentiation of the self, triangulation, cutoff, family projection process, multigenerational transmission process, sibling position, and the societal emotional process (Bowen, 2002; also see Freidman, 1991; Gilbert, 2006; Hall, 1981; Papero, 2006; Payne, 1997). This paper focuses specifically on FST, but future research discussed at the end of the paper suggests ways to link the two theories to further expand the usage.
} 